enroll in doctoral programs in political science in the United States.

Since the potential applicant pool is small, fellowships would not necessarily be awarded every year. Reviews will be made by two readers selected by the APSA President, and by the APSA Director of Minority Affairs. Students interested in applying should write to APSA for further information and application forms before December 1, 1994.

The Native American Policy Network, chaired by Maggi Murdock, University of Wyoming, and other political scientists, requested that APSA take this step and were active in advancing it. The Native Americans Policy Network meets regularly as a Related Group in conjunction with the APSA Annual Meeting.

Numbers of Native Americans in political science are small. The Departmental Survey shows actual responses from 7 full-time Native American faculty ( 6 men and 1 woman), which on a weighted basis suggests there are 12 full-time $\mathrm{Na}$ tive American political science faculty nationally. Eighteen current APSA members identify themselves as Native American-6 students and 12 regular members.

The Doctorate Records Project of the National Research Council reports that two Native American students earned Ph.D.'s in political science in 1991. This is $1.5 \%$ of all Ph.D.'s earned by Native American students that year; $1.7 \%$ of all Ph.D.'s received by anyone are awarded in political science.

\section{Dutch Students Participate in APSA Program on American Politics}

Last winter, Joost de Wals, a student of political science at Katholieke Universiteit in Nijmegen, Holland, contacted the Association in need of assistance. De Wals had been directed to the APSA by Nijmegen faculty who were Association members. He told Robert Hauck, Director of International Programs, that in celebration of the university's 75 th anniversary, a group of graduate students in political science would be traveling to the United States to look closely at the American political system and to see how public policy is made. The group intended to visit Boston, New York, and Washington. Could the APSA suggest people or organizations to contact to help fill the week they planned to spend in Washington?

The Association is no stranger to hosting international groups. Programs were already in the offing for parliamentary interns from Canada, educators and journalists from Argentina, and journalists from Bolivia. Taking advantage of working with international students as well as serving its international members, Hauck offered the Association's help in putting together a week of events for the group. De Wals agreed and the result, by all accounts, was an undiluted success.

On Monday, April 18, after months of planning, APSA Executive Director Cathy Rudder, Hauck, and program coordinators David Stiepleman and Sean Twombly of the staff welcomed the Dutch group to Washington. The inaugural lecture was delivered by Senator Richard Lugar (R-IN) on the subject of NATO and its role in the post-Cold War world. The group from Nijmegen was joined by 20 Canadian Parliamentary Interns, guests of the APSA's Congressional Fellowship Program.

The complete program consisted of four days of tours and seminars presented by leading figures in politics and policymaking. Representative John Lewis (D-GA), spoke with passion about coming of age in the segregated South and on the legacy of the Civil Rights movement. Dr. William Galston, Deputy Assistant to the President for Domestic Policy and a former member of the political science faculty at the University of Maryland-College Park, welcomed the group to the Roosevelt Room of the White House and discussed the Clinton Administration's efforts with health care and welfare reform. Galston emphasized the vital importance of coordination with key legislators on Capitol Hill. Steve Horn (R-CA), a political scientist and former APSA
Congressional Fellow, reflected on his first year in the House of Representatives and made the case that an antiquated committee system was to blame for congressional gridlock. Ron Elving, another former Congressional Fellow and political editor at Congressional Quarterly, gave a detailed, insider's look at how a bill becomes a law, drawing his points from parental leave legislation. Bruce Jentleson, a political scientist and currently serving in the State Department's Office of Policy Planning, offered his thoughts on how the Bosnian crisis might influence future U.S. foreign policy. Dr. Richard Baker, Historian of the U.S. Senate, traced the evolution of the body and offered observations on the institutional differences between the Senate and the House of Representatives. Cornelius Heine of the Capitol Historical Society led an insider's tour of the United States Capitol.

A heated discussion ensued following a tour and briefing at the Pentagon. The Dutch group brought up comparisons between the Dutch military's practice of allowing homosexuals to serve without incident and the American military's "don't ask, don't tell" policy. The Dutch students were joined at the Pentagon by the Canadian Parliamentary Interns.

The Dutch group, astute students of American politics and not at all hesitant to ask penetrating questions, found the program well-balanced and informative. They were also pleased with a Wednesday afternoon chance encounter with Hillary Rodham Clinton in the West Wing of the White House.

At an informal dinner at the end of the week, the Dutch group offered a donation to the APSA in appreciation of the program. The gift, $\$ 400$ in personal contributions, will be put toward the 1994 Annual Meeting Graduate Student Travel Grants.

\section{Live from Washington: Distance Learning in Russia}

In cooperation with the United States Information Agency, the 